\title{
Legal support of the achievements of modern scientific and technological progress of transport in the agro-industrial complex
}

\author{
Elena Yakovleva $^{1, *}$ and Vladimir Tarykin ${ }^{1}$ \\ ${ }^{1}$ Southwest State University, 94, str. 50 years of October, 305040, Kursk, Russia
}

\begin{abstract}
Problems of ensuring health safety and environmental protection both in separate regions of the country and in the whole Russian territory are directly connected with solving the issues of humanity's use of the most environmentally "sparing" means of management if we speak about transport industry, which belongs to the category of the most demanded among civil population on one hand, and the most influential on the condition of atmospheric environment pollution on the other. It is believed that one of the most optimal solutions in this area (in terms of the reduction of gas emissions and economic efficiency) is the transition of modern automakers to unmanned vehicles and eco-cars, many of which can already allow the complete elimination of driver participation in the driving of the car. By 2030, the transition to such vehicles will become quite commonplace, at a time when a decade ago the current reality, born of an active leap in the development of scientific and technological progress, seemed fantastic. However, while pursuing well-intentioned goals, such as those related to the reduction of greenhouse gas emissions of unmanned electric vehicles, there are a number of related problems that have not yet found their solution, mostly related to the quality of the legal torts.
\end{abstract}

\section{Introduction}

Questions of maintenance of a transport security in new vital conditions from a position of the problems caused by collisions in the right, occurrence new criminological threats, complication of technical transport park of the country, creation of the modern intellectual transportation systems, kept risks of terrorist threats and cyber attacks as well as introduction of new educational programs of training of the professional staff, were not considered earlier in a cut of the uniform complex program that requires separate studying and gives a special urgency to the present research. Modern researches in the field of maintenance of an ecological security and the prevention of some the dangerous diseases developing in conditions of the polluted environment from operation of a transport complex of the country, should be solved in a complex with a legal position of the legislator. In particular, separate modern scientific objectives should become also not only development uniform concept to understanding differentiation of measures of the legal responsibility of

*Corresponding author: pragmatik-alenka@yandex.ru 
system « the driver-transport means-artificial intelligence-is dear » on the basis of the complex interdisciplinary analysis legal and organizational-means maintenance of a transport security, but also the subsequent development of offers on perfection of relationships of subjects of a motor transportation infrastructure and the prevention of crime encroachments on it. The decision of such objectives lays in a plane of achievement of some the problems connected with: development categorical the device of such concepts as: a mechanical vehicle "," a pilotless vehicle "," the robot "," robocar "," an artificial intellect "," the autopilot » with definition of their distinctive properties and signs in a combination to the analysis of public attitudes in area of a safety of traffic as separate object criminally a-right protection; carrying out of the retrospective analysis of development of norms about the responsibility for fulfilment of careless road and transport crimes in comparison with actual edition of the law; a legal and statistical assessment of a condition of careless criminality and a traumatism on transport in Russia and abroad ; the rather-legal analysis of world tendencies of criminal policy and separate legislations of the countries providing the responsibility for fulfilment of road accident, including with use of technologies of an artificial intellect; research of features of criminally-legal assessment of objective and subjective signs of the road crimes accomplished with use of technologies of an artificial intellect; development of specific measures of criminally-legal influence focused on the person guilty, based on their data socially-demographic and psycho physiological of properties (from a position of evolution metacognitive diagrams of the person); development of separate offers on the modernization of the criminal legislation connected with preparation of new editions of structures of crimes, providing the responsibility in considered subjects of criminal actions; definition of modern vectors in progress of criminal policy and scientific researches of Russia on a way to harmonization and integrated approach in the decision of a problem unsettled legislations in area of fulfilment of careless criminal actions with use of robots and technologies of an artificial intellect; aassessment of an actual condition of a transport infrastructure of Russia, with revealing the major factors which are influencing potential of financing of branch; consideration of the basic theoretical approaches to definition of concept and essence of an active and passive security of the car; revealing of existing systems of the help to the driver; carrying out of interrogation of consumers regarding the attitude to existing systems of the help to drivers and introduction of systems of an artificial intellect; the analysis of existing methods of an assessment of a condition of breakdown susceptibility, disputed situations and influences of the human factor on parameters of breakdown susceptibility; the analysis of investigative techniques of probability of occurrence of road accident and factors of influence and existing methods of definition of a functional condition of the person with definition of a degree of its influence on speed of performance of operations and probability fulfilment road accident.

Principle questions of civil liability for damage caused by actions of robotic control means were touched by: E.N. Iriskina, K.O. Belyakov, O.A. Yastrebov et al. The issues of criminal-legal provision of transport security and threats to criminological security in transport were devoted to the works of such authors as: G. G. Kamalova, E. V. Medvedev, N. L. Shelukhin and others. The issues of reckless criminality, as well as criminal or criminological characteristics of crimes committed on transport are well enough studied in science. To the scientific works of such specificity can be referred works of: Y.M. Antonyan, D.A. Brazhnikov, M.V. Goncharova, P.S. Dagel, M.Y. Zelenkov, N.I. Isaev, A.I. Korobeev, A.A. Matveev, S.V. Malikov, A.I. Chuchaev, V.E. Eminov and others. However, despite the multiplicity of works by the above author and many others, we note that previously a single comprehensive study with an interdisciplinary character has not been conducted. New modern trends in the technical development of the country's transport fleet have not been taken into account, including those that got their start during the 
pandemic crisis, expressed in the reduction of public transportation and the transition of more and more citizens to the use of private motor vehicles.

\section{Methods}

The totality of research methods includes, first of all, materialistic dialectics. In addition to this fundamental method of scientific knowledge, we used traditional for theoretical and applied legal research general scientific, private scientific and special methods - the method of comparative law, the method of legal interpretation, system-structural, statistical, correlation, sociological, content analysis of scientific publications, various types of extrapolation and others.

\section{Results}

The main result of the study is the definition of the main modern problems of stage robotization of the transport complex of the country, requiring its logical and scientifically argued solution through the execution of a number of tasks identified in the course of this study.

Table 1. Name of the problem and description.

\begin{tabular}{|c|c|c|}
\hline № & Name of the problem & Description \\
\hline 1. & $\begin{array}{l}\text { Complete absence of regulatory } \\
\text { and technical regulation of the } \\
\text { basis and conditions for the } \\
\text { development and launch, control } \\
\text { over the result of artificial } \\
\text { intelligence and vehicles created } \\
\text { on its basis. }\end{array}$ & $\begin{array}{l}\text { The use of artificial intelligence in transportation now } \\
\text { has a number of problems, both of a minor nature (for } \\
\text { example, periodic failures of mobile applications that } \\
\text { prohibit access to cars or the use of solar panels, as } \\
\text { well as Powerwall energy storage systems caused by } \\
\text { data center problems) and having a real threat to the } \\
\text { lives and health of drivers and passengers in case of } \\
\text { spontaneous ignition of electric vehicles. In spite of } \\
\text { this state of affairs, there is still a separate interest in } \\
\text { transportation based on artificial intelligence and } \\
\text { automated control in Russia. }\end{array}$ \\
\hline 2. & $\begin{array}{l}\text { Lack of a uniform understanding } \\
\text { of the approach to the legal } \\
\text { support of the use and } \\
\text { development of artificial } \\
\text { intelligence systems in the } \\
\text { transport industry, as well as little } \\
\text { assessment of the risks arising } \\
\text { from accidents involving robotic } \\
\text { controls. }\end{array}$ & $\begin{array}{l}\text { Such a problem is caused by contradictions and } \\
\text { conflicts of interest in determining the degree of legal } \\
\text { responsibility between manufacturers and subjects of } \\
\text { use of vehicles equipped with artificial intelligence. } \\
\text { The solution of the problem in the scientific study } \\
\text { should be the starting point in determining the "legal } \\
\text { status" of artificial intelligence in the transport } \\
\text { industry. }\end{array}$ \\
\hline 3. & $\begin{array}{l}\text { The problem of finding the } \\
\text { optimal model of combining law, } \\
\text { morality and justice, technology } \\
\text { and ethics. }\end{array}$ & $\begin{array}{l}\text { Dictated by large-scale motorization in Russia and the } \\
\text { world this problem is indicated, including the legal } \\
\text { position of developers of algorithms of artificial } \\
\text { intelligence and vehicle manufacturers, as possible } \\
\text { carriers of criminal responsibility for causing harm by } \\
\text { their "creation". Therefore, a search for optimal } \\
\text { models of combining all of these elements in scientific } \\
\text { research is necessary, as it comes down not only to the } \\
\text { moral, but also to the ethical side of the question of } \\
\text { how a machine should behave in an unavoidable } \\
\text { emergency situation. Whether it will prioritize between } \\
\text { human life and causing significant property damage, } \\
\text { or, for example, between preserving the life of the }\end{array}$ \\
\hline
\end{tabular}




\begin{tabular}{|c|c|c|}
\hline & & $\begin{array}{l}\text { driver or a pedestrian. Hence, the purpose of robotic } \\
\text { vehicles goes far beyond the expected results, raising } \\
\text { doubts about the fundamental possibilities of } \\
\text { combining the concepts of fairness, objectivity, and } \\
\text { reasonableness in them simultaneously. }\end{array}$ \\
\hline 4. & $\begin{array}{l}\text { The problem of growth of threats } \\
\text { of transboundary nature, causing } \\
\text { the need to rethink new sources } \\
\text { of increased danger, requiring a } \\
\text { scientifically based development } \\
\text { of declarative solutions in the } \\
\text { field of ensuring not only national } \\
\text { but also international security. }\end{array}$ & $\begin{array}{l}\text { Scientific research involves a comprehensive analysis } \\
\text { of the norms of responsibility for negligent infliction } \\
\text { of harm, which is the majority of the considered acts } \\
\text { committed by drivers using robotic controls. However, } \\
\text { such types of acts that can be committed intentionally } \\
\text { with the use of transport as a means of crime should } \\
\text { not be ignored. For example, the illegal transportation } \\
\text { of narcotic drugs and psychotropic substances using } \\
\text { drones. }\end{array}$ \\
\hline 5. & $\begin{array}{l}\text { The difficulty of the modern legal } \\
\text { system to work ahead of or in the } \\
\text { perspective of criminal threats. }\end{array}$ & $\begin{array}{l}\text { The need to develop in scientific research conceptual } \\
\text { provisions, as well as prognostically supported } \\
\text { approaches to the formation of a unified system of } \\
\text { legal security in the field of road safety. }\end{array}$ \\
\hline 6. & $\begin{array}{l}\text { The problem of the exclusive } \\
\text { impossibility of applying } \\
\text { traditional forms of criminal } \\
\text { liability for the commission of } \\
\text { accidents, as applied to situations } \\
\text { where the driver used the } \\
\text { "atopilot" mode. }\end{array}$ & $\begin{array}{l}\text { So far, the majority of modern modes of transport, do } \\
\text { not exclude the complete impartiality of the driver in } \\
\text { the implementation of maneuvering. Therefore, there } \\
\text { are justifiable problems of provability of the moment } \\
\text { of his being behind the wheel in the mode of self- } \\
\text { government. These issues are debatable, but they } \\
\text { should remain a priority both for investigative and } \\
\text { judicial practice, and for the development of the } \\
\text { concept of modern Russian criminal policy in the era } \\
\text { of robotization, as well as for scientific research. }\end{array}$ \\
\hline 7. & Lack of detailed terminology & $\begin{array}{l}\text { For example, the wording ("robot", "artificial } \\
\text { intelligence", "vehicle and mechanical vehicle", etc.) } \\
\text { in the construction of the legislative framework, which } \\
\text { regulates the procedure and conditions of prosecution } \\
\text { for committing road accidents using artificial } \\
\text { intelligence technology. Which necessitates the need } \\
\text { for legal "filling" of the conceptual apparatus. }\end{array}$ \\
\hline 8. & $\begin{array}{l}\text { Insufficient professionalism of } \\
\text { drivers, lacking the skills to } \\
\text { respond quickly to stressful } \\
\text { situations, the basics of } \\
\text { maneuvering the vehicle, even } \\
\text { being in automatic control of } \\
\text { sources of increased danger. }\end{array}$ & $\begin{array}{l}\text { It is necessary to develop algorithms of actions in } \\
\text { typical and atypical emergency situations in conditions } \\
\text { of driving a robotic vehicle, to develop and normative- } \\
\text { legal fixation of bases and methods of diagnostics of } \\
\text { psychological professional aptitude of drivers, and also } \\
\text { to prepare methods of their professional retraining. }\end{array}$ \\
\hline
\end{tabular}

\section{Discussion}

Life in the new conditions, born of the consequences of the spread of coronavirus infection, forced to think about the predetermination of many priorities and the setting of values of everyone. Problems of urgent response, choice of methodical approaches, reallocation of resources, and as a result, decision-making and execution in the absence of analogues or patterns of behavior could not be personalized at all. Therefore, the emerging involuntary socio-economic situation in the country forced to rethink the main vectors of development of public policy in Russia [1,2], and in some cases completely abandon the previous planned ideas. Such a difficult decision was made by the President of Russia, for example, as part of the implementation of ideas of strategic importance, previously designated by Presidential Decree of May 7, 2018. №204 "On the national goals and strategic objectives 
of the development of the Russian Federation for the period up to 2024", where the national goal to bring Russia into the top five economies of the world disappeared due to the "unfavorable economic international conjuncture"[3]. However, despite the complexity of overcoming the problems of the pandemic crisis, in 2021 the government apparatus managed to maintain the financial capacity to support many national projects. As V.V. Putin: "national projects are of decisive importance for the economy and social sphere of the whole country, all regions. People should feel the positive effect of the national projects, which, in the end, are aimed primarily at improving the quality of life of the country's citizens. At the same time, "already in 2021 a qualitative, tangible result must be ensured for each national goal," Putin said, urging not to put off solving complex, problematic issues "for later". [4] Such a position of the head of state undoubtedly stimulates the continuation of coordinated work on various social spheres. In execution of such instructions should be taken socially significant, balanced and fair decisions, capable of becoming a real support for the Russian people. However, there are many problems standing in the way of such decisions, including those in the legal field.

One of the most urgent areas includes ensuring transport security, as transport infrastructure has a key aspect in the interaction of regions of the country and interstate communications, which serves as a guarantee of beneficial economic development. "Now there are reserves in the transport system of Russia, it is necessary to use them by all means, to give loading to domestic companies, to realize the geographical advantages of our country in the interests of the national economy and our citizens", - emphasizes the head of state [5]. Especially acute problem of the use of financial reserves of the country concerns motor transport infrastructure, as the most widespread and demanded by consumers of the market. Undoubtedly, the cost equivalent of the issue under consideration is directly related to a number of related tasks. In the conditions of the transitional stage in view of the return to at least pre-crisis indicators in the road transport sector there is a transformation of the image aimed at expanding the potential boundaries. Therefore, it is true to judge the priority position of this industry among other types of transport when it comes to ensuring transport security. The increased risk of spreading infection on public transport has caused many citizens to switch to private cars. At the same time, the search for ways out of the crisis has forced manufacturers to think about the use of innovative technologies in the design of their products, making them the most attractive, safe and economical [6].

Experts from IBM Corporation (USA) believe that automated highways will be created, where cars will be connected to the system to automatically change their direction and optimize traffic flows. Intelligent roads can reduce traffic jams. The first priority in this direction is to collect data on all the routes that people, cars, goods and goods actually travel within the urban area. Then, innovative ways will be needed to apply this data to solve existing traffic difficulties [7].

Thus, the goals outlined in the national project of the Russian Federation "Safe and quality roads 2019-2024", and subsequently extended until 2030 due to the unstable economic situation, are directly related to solving the most important task of not only the Russian, but also the global community - to create a transport infrastructure that meets the requirements of efficiency, comfort and safety for citizens. At that, in our opinion, the statement that aims to reduce the mortality rate on the roads to 4 people per 100 thousand by 2024 and to zero by 2030 sounds quite resoundingly [8]. After all, according to forecasts, in the absence of consistent countermeasures by 2030. Road accidents will become the seventh leading cause of death. Every year more than 1.25 million people lose their lives as a result of road accidents. Between 20 and 50 million people suffer non-fatal injuries, many of which result in disability. [9] The significant number of accidents caused by the intensification of the car fleet, with a decreasing trend in the number of fatalities, according to statistical data presented on the official websites of the Russian Ministry of 
Internal Affairs, can be explained by the development of active and passive safety systems based on the implementation of intelligent systems to help drivers who have a genuine interest in vehicle safety along with a similar interest of automakers themselves, seeking to meet the demand with product quality to the maximum.[10]

The era of robotization has begun. The digitalization of almost all spheres of life, the introduction of artificial intelligence, the transition to nano-technology, and threedimensional imaging, which has caught up with humanity, has led to scientific debates and discussions that go far beyond domestic politics to the international level. Drones, electric cars and drones, intelligent warning and navigation systems, machine vision modules that recognize pedestrians, which once seemed fantastic, have already been successfully mastered by humans. Modern BIM-technologies, creation of digital twins and geoportals, GLONASS, interactive crosswalk systems, photo-video fixation cameras, MedPoint24 examination systems, application of incident management and acoustic road sensors nowadays they logically fit into the concepts of the unified intellectual transport system development. Tesla's policy in developing autonomous vehicles has been one of the most aggressive, and this is one of the reasons for its unambiguous leadership in the unmanned car market. Tesla was the first to incorporate extensive autopilot features into its vehicle control system, which can take control of steering, braking, and switching lines. In July 2016, the first accident involving an unmanned car occurred when the Tesla Model S crashed into a truck making a turn in front of the car - the autopilot failed to recognize the white body of the truck against the white sky. [11] The media propaganda of autonomous vehicle ideas is gaining momentum due to the interest of the consumer market. Thus, according to the analytical agency Avtostat, "today $60 \%$ of American consumers are ready to buy an autonomous car, and $70 \%$ are willing to get it for a test drive; according to the Boston Consulting Group forecasts, by 2025 there will be more than 12 million autonomous cars in the world" [12]. The struggle for the leading position in the race of the transport industry will steadily lead to the commonplace human use of future technologies, for example, unmanned cars, which once seemed fantastic. Nevertheless, most of such technologies are already on the market today. For example, Advanced Driver Assistance Systems - ADAS - are built-in features that help the driver avoid an accident (active safety) or reduce the severity of its consequences (passive safety). Modern driver assistance systems can be implemented directly as well as offering promptings and warnings.

Hence, according to a number of authors [13], there is a question that has not yet found an unambiguous answer - who will eventually be destined to control the fate of a particular life situation - a person or a robot? After all, a mistake in such a choice carries an enormous risk for the life and health of citizens. The integration of digital and transport is accompanied by a number of problems related not only to the lack of training in working with digitalization products, the presence of corruption and cyberthreats, the lack of a unified regulatory framework, but also the lack of educational programs that meet the continuous development of the NTT, and thus the lack of personnel capable of making the right qualification, for example, in the case of a robot causing the death of a person. Training of personnel capable of acting efficiently in the ITS industry, making the right decision when control of such a system is "paralyzed", making competent expert examination, correctly assessing legal risks and emergency situations, giving competent qualification and imposing fair punishment, should become the main vector for the community, along with the stimulation of scientific potential for the continuation of scientific research, updating legal and regulatory acts, and preparing ethical codes of practice and guidelines The technical and innovative transformation of the country's vehicle fleet will take place in the next decade. Therefore, identifying the factors that significantly affect the risk of accidents while improving safety is a global priority. 
Separate attention should be paid to such tasks as strengthening the legal responsibility of drivers for unlawful actions, as well as increasing the requirements to the level of their professional training and retraining.[14] As can be seen from the above list of goals and objectives facing society, only in the industry of the future transformation of the automotive industry, there is a significant number of "bottlenecks", the solution of which should already find answers, exclusively applying cross-sector knowledge of transport security The economic profitability of using one or another mode of transport directly depends on the use of modern scientific and technological progress. Innovative processes actively introduced at transport infrastructure facilities are subject to risks and deliberate criminal encroachments, and in some cases cyber attacks [1]. Risks of terrorist threats persist. There are difficulties with the proper qualifications of citizens, their untrained to use the results of the achievements of new technologies, a low degree of preparedness for stressful situations. In the link of each link among the above there are unambiguous risks to the safety of citizens, the role of careless acts in the overall structure of crime increases, which cannot but cause doubt about the need for prospective legal regulation of the relationship under consideration with the application of studies of legal profile, criminological, technical, economic, social, psychological and others.

At the same time, the current instability in the economy involves the search for internal reserves and effective use of existing potential, creation and comprehension of a new adaptive model of development. This circumstance prompts the search for new areas of economic optimization, in particular the criminal-legal sector. Given the fact that this sector is the most economically costly, it is necessary to take a set of decisions, including at the legislative level, aimed at reducing the cost of criminal proceedings on the one hand, and increasing the budget profitability in the implementation of criminal law institutions of property nature (fines, court fines, confiscation of property, release from criminal liability in connection with compensation for damages, other types of release from criminal liability and punishment, where one of the key conditions is to The problematic nature of the issue is characterized, among other things, by the dual nature of understanding and lack of conceptual and categorical apparatus of economization of criminal law. [15]

The forthcoming changes, including those associated with the introduction of unmanned cars based on artificial intelligence, should already find options for legal regulation. However, now they are on the plane of traditional understanding of the mechanism of criminal behavior and the subject of the crime, referring the actions of drivers to the signs of corpus delicti of Art. 264, Art. 264.1 of the Criminal Code, which casts doubt on the causal link between the specific actions of the guilty at the time of the accident and the occurred consequences. Development of legislation should take into account the trends of socially dangerous acts, so the study of issues of criminal liability for reckless crimes committed with the use of artificial intelligence is of particular importance. In particular, it is necessary to modernize the criminal-law norms, by including separate qualifying features on the corpus delicti for careless crimes, providing for the liability of drivers for accidents committed with the use of an autopilot system. So far, such a system has not received "legal status" either from the legislator or from the manufacturer companies, which is wrongly interpreted not in favor of drivers, attributing their actions completely and unconditionally to negligence.

\section{Conclusion}

On the basis of the analysis of the existing problems, which are of debatable nature, it is possible to identify current trends in the development of scientific research in the field of knowledge under consideration. We refer to them: 1. Expansion of theoretical knowledge concerning new legal categories, the development of social relations in the field of road 
safety; 2. Expansion of theoretical knowledge about the legal nature, mechanism of criminal behavior, the structure of transport crime, patterns of situational approach, the role of metacognition in the formation and evolution of personality behavior schemes; 3 . Obtaining new scientific knowledge about the current state and scientific-technical development of transport industry, global trends of artificial intelligence, sociodemographic and psychophysiological characteristics of the personality of drivers, assessment of public opinion on the issue of determining the subjects of responsibility for the consequences caused by the use of artificial intelligence technology in transport; 4 . theoretical justification of the need to modernize the national criminal legislation in relation to Determination of specific features of objective and subjective features of transport crimes committed with the use of robotic systems, as well as identifying the risks of their use, followed by the development of criminal-legal assessment;6. Elaboration of specific proposals related to the prevention of road crime in Russia, including crimes committed with the use of robotic vehicles;7. Development of new methods of professional training and retraining of drivers with the use of technical control and informatization, as well as new coping strategies as a means of self-control of the driver in stressful situations;8. Discovery of new vectors of using research results in creating algorithms of action model of ethical choice by robotic vehicles in provocative conditions.

\section{References}

1. E.O. Yakovleva, Bulletin of Tomsk State University. Law 36, 136-144 (2020) DOI: $10.17223 / 22253513 / 36 / 12$

2. E. Yakovleva, V. Tarykin, G. Plohih, M. Ovsyannikova, Proceedings of the 35th International Business Information Management Association Conference (IBIMA) (International Business Information Management Association (IBIMA), Seville, 2020)

3. Citizens care about the result, https://tass.ru/nacionalnye-proekty/6415134

4. K. Latukhina, Tasks for time, https://rg.ru/2020/09/29/putin-prizval-ne-otkladyvatnacionalnye-proekty-na-potom.html

5. L. Iz'yurova, Observer of "TS". In conditions of pandemic, https://transportrussia.ru/item/5566-v-usloviyakh-pandemii.html

6. A.A. Grebenkov, E.O. Yakovleva, International Journal of Applied Engineering Research 11(9), 6832-6834 (2016) ISSN 0973-4562

7. Transportation in the context of COVID-19. Department of International and Regional Cooperation, https://ach.gov.ru/upload/pdf/Covid-19-transport.pdf

8. Medvedev signed the strategy of road safety, https://rg.ru/2018/01/22/medvedevpodpisal-novuiu-strategiiu-bezopasnosti-dorozhnogo-dvizheniia.html

9. World Health Organization. Road traffic injuries, http://www.who.int/ru/newsroom/fact-sheets/detail/road-traffic-injuries

10. E.O. Yakovleva, The personality of the driver and the situation in the mechanism of committing road traffic crimes: monograph (Yurlitinform, Moscow, 2016)

11. Race for 2021: who's who in the market of unmanned cars, https://vc.ru/transport/23330-the-race-to-2021

12. Cars of the future: what cars will be like in 10 years, http://https://nearfuture.ru/avtomobili-budushhego-kakimi-stanut-mashiny-cherez-10-let/

13. S. Sheveleva, E. Bakovleva, IOP Conference Series: Materials Science and Engineering 918 (2020) 
14. E.O. Efimova, Izvestia of Southwestern State University. Series: History and Law 1, 78-83 (2013)

15. S.V. Sheveleva, E.O. Yakovleva, Bulletin of the Volgograd Academy of the Ministry of Internal Affairs of Russia 2(53), 41-47 (2020) 